\title{
Hepatoprotective Effect of Moringa oleifera Leaves and Seeds Powder on Carbon Tetrachloride Induced Hepatotoxicity in Rats
}

\begin{abstract}
The main objective of this study was to investigate the effect of supplementing CCL4-exposed male Sprague Dawley albino rats with 10 and $5 \%$ leaves and seeds powder of Moringa oleifera Lam (Moringaceae, M. oleifera) respectively on liver functions. The experiment was carried out on 40 male Albino rats divided into 5 equal groups; $1^{\text {st }}$ group fed on basal diet and kept as a (control-). Rats in the other four groups $(n=32)$ were intoxicated by subcutaneous injection of $\mathrm{CCl}_{4}(2 \mathrm{ml} / \mathrm{kg})$ twice a week for two consecutive weeks to induce hepatic chronic damage, then those rats were subdivided into: a group that control positive (control+) [ $2^{\text {nd }}$ group], a group that fed on basal diet + Moringa oleifera leaves powder $10 \%$ [3 ${ }^{\text {rd }}$ group]; a group that fed on basal diet + Moringa oleifera seeds powder $5 \%$ [ $^{\text {th }}$ group]; a group that fed on basal diet + silymarin whereas silymarin-treated was orally administrated with silymarin $50 \mathrm{mg} / \mathrm{kg}$ [5 ${ }^{\text {th }}$ group]. The results showed that the total cholesterol, triglycerides, LDL-C, AST, ALT, and urea levels decreased significantly with treated rats with Moringa oleifera powder, and the best result was belonged to the group of rats that fed on Moringa oleifera leaves $10 \%$. It can be concluded that, supplementation with high percentage of Moringa oleifera exerts a positive impact on the liver functions, lipid profile and other biochemical parameters.
\end{abstract}

Suzan A. Abushal 2012).
Key words: Moringa oleifera, Antioxidants, biochemical parameters, Rats.

\section{INTRODUCTION}

Herbal medicine is one of the oldest forms of treatment for diverse ailments and it has enjoyed a relatively high subscription for obvious reasons like being cost effective, accessible, and it blends with socio- cultural life of the people. WHO has stated that herbal or medicinal plants are the best source to obtain a variety of drugs. Moringa oleifera popularly known as miracle tree or drumstick tree in Nigeria is highly valued and most cultivated species of the monogenetic family Moringaceae. It is cultivated widely both in the tropics and subtropics (Ajayi, et al., 2016).

Moringa oleifera Lam (Moringaceae, M. oleifera) is a highly nutrient-rich plant with exceptional medicinal properties widely used to treat various health care problems (Farooq, et al., 2012). It provides a rich combination of nutrients, amino acids, antioxidants, anti-aging and anti-inflammatory compounds and is employed as medication for a variety of ailments particularly in South Asia and India. Since 1998, the World Health Organization has promoted Moringa as an alternative to imported food supplies to treat malnutrition. In addition to the important medicinal properties and high nutritional value of various parts of this plant such as leaves, roots, seeds, bark, fruit, flowers and immature pods, it also has a potent water purifying property (Anwar, et al., 2007). Not surprisingly, M. oleifera is sometimes described as "Mother's Best Friend", "Miracle Tree", "Tree of Life" and "God's Gift to Man" (Johnson, 2005; Mbikay,

Moringa oleifera (MO) is cultivated in many tropical and subtropical countries of Asia and Africa. It is commonly known there as the drumstick tree or horseradish tree (Mbikay, 2012), while in the Nile valley, its name is 'Shagara al Rauwaq', which means 'tree for purifying' (Von Maydell, 1986). It is used as a leafy vegetable with leaves that can be eaten fresh, cooked, or stored as dried powder for many months without refrigeration, and with- out loss of nutritional value (Anwar et al., 2007).

The therapeutic effects of Moringa oleifera leaves have been attributed to the combined actions of various bioactive components found in the plant that include trace metal ions, especially potassium, calcium, phosphorous, zinc, manganese and iron, vitamins A, D, E and C (Aslam, et al., 2005; Gowrishankar, et al., 2010), alkaloids such as moringi- nine, carotenoids such as p-carotene and essential amino acids (Amaglo et al., 2010). Moreover, M. oleifera contains three structural classes of phytochemicals which have several medicinal benefits. They are glucosinolates such as glucomoringin, flavonoids such as quercetin and kaempferol and phenolic acids such as chlorogenic acid (Mbikay, 2012). These phytochemicals have been reported to possess antioxidant, hypoglycemic, hypotensive, antidyslipidemic, anticancer, and anti-inflammatory

DOI: 10.21608/ASEJAIQJSAE.2020.115132

${ }^{1}$ Food Science and Nutrition Department, Turabah University College, Taif University

Kingdom of Saudi Arabia Ministry of Education

Corresponding author: E.mail; S.aboshal@tu.edu.sa

E.mail: sozanabushal@yahoo.com

Received August 26, 2020, Accepted, September 25, 2020. 
properties (Lako, et al., 2007; Manguro and Lemmen, 2007; Amaglo, et al., 2010; Kasolo, et al., 2010).

Kou et al , (2018) documented multiple functions, i ncluding hepatoprotective,hypoglycemic and blood lipid reducing functions in the Moringa oleifera extracts.

Moringa oleifera's positive roles are closely correla ted with its phytochemicals such as flavonoids or bioacti ve isothiocyanates.

This study was designed to investigate the hepatoprotective effect of Moringa oleifera leaves and seeds on carbon tetrachloride induced hepatotoxicity in rats.

\section{MATERIALS AND METHODS}

\section{Material:}

Fresh leaves of Moringa oleifera and Moringa seeds were purchased from a local herbal medicine shop in Jeddah, KSA.

Casein (85\% protein), cellulose and D-L methionine, vitamins and minerals constituents and all chemicals used in this experiment were of analytical grade. Corn oil and corn starch were obtained from the local market. Kits used for the quantitative determination of the different parameters were obtained from Al-Saudi Company \& Chem., Jeddah, KSA.

40 male Albino rats of Sprague Dawley strain weighing about $(200 \pm 10 \mathrm{~g})$ obtained from Medical Research Center of King Fahd Jeddah KSA..

\section{Methods:}

\section{Preparation of Moringa oleifera powder.}

The Moringa oleifera seeds were washed, air dried, milled by the mixer and Moringa oleifera leaves were washed with running tap water and dried, the dried leaves and seeds were ground into fine powder and kept in tightly closed containers at room temperature.

\section{Biological assay:}

40 male albino rats Sprague Dawley strain weighing $(200 \pm 10 \mathrm{~g})$ were housed in well aerated cages under hygienic condition $\left(\left(22 \pm 1^{\circ} \mathrm{C}, 12 \mathrm{~h}\right.\right.$ light $/ 12 \mathrm{~h}$ dark cycle), fed on basal diet and water ad-libitum for one week before experiments in Medical Research Center of King Fahd Jeddah. All experimental protocols were approved by the Animal Experimentation Ethics Committee of the king abdulaziz University, KSA. The basal diet consists of casein $12.5 \%$, Corn oil $10 \%$, choline chloride $0.25 \%$, vitamin mixture $1 \%$ (Campbell, 1963), salt mixture 4\% (Hegested, et al. 1941), cellulose $5 \%$, and the remainder $(71.07 \%)$ is corn starch (Reeves, et al ., 1993), and this diet was modified in its content of (casein \& starch) before giving to the groups fed on Moringa oleifera powder leaves and seeds (10\% and 5\%) respectively.
After the period of adaptation on basal diet, the rats were divided into 2 groups, the first group fed on basal diet as a control negative, the second main category $(n=32)$ rats were intoxicated by subcutaneous injection of $\mathrm{CCl}_{4}$ in paraffin oil $(1: 1 \mathrm{v} / \mathrm{v} ; 2 \mathrm{ml} / \mathrm{kg})$ twice a week for two consecutive weeks to induce hepatic chronic damage (Jayasekhar, et al., 1997). After that, the rats were divided into four major groups. The second group fed on basal diet (control positive), the third group fed on basal diet + Moringa oleifera powder $10 \%$ (MOLP10\%), the fourth group fed on basal diet + Moringa oleifera seeds powder 5\% (MOSP 5\%), the fifth group fed on basal diet + (silymarin), whereas silymarin-treated was orally administrated with silymarin $50 \mathrm{mg} / \mathrm{kg}$ dissolved in $0.5 \%$ sodium carboxymethyl cellulose (CMC-Na) distilled water solution (Alcaraz-Contreras, 2016).

\section{Haematology and serum biochemical studies}

At the end of the 6 weeks of treatment, each rat was bled through the orbital sinus into heparinised bottles tubes for haematological studies and blood samples collected in clean non-heparinised bottles tubes were allowed to clot. The serum was separated from the clot and centrifuged into clean bottles for biochemical analysis. Packed cell volume (PCV) and haemoglobin concentration were determined by the microhematocrit and cyanmethaemoglobin methods, respectively, as described by (Jahn, 1988). Erythrocyte count was determined by the haematocytometry method as described by (Jahn, 1988). Erythrocyte indices including mean corpuscular volume (MCV), mean corpuscular haemoglobin $(\mathrm{MCH})$ and mean corpuscular haemoglobin concentration (MCHC) were determined from the values obtained from red blood cells (RBC) count, haemoglobin concentration and PCV values (Duncan, et al., 1994). Total Leukocyte (TLC) counts were made in a haemocytometer using the TLC diluting fluid and differential leucocytes counts were made by counting the different types of TLC from giemsa stained slides viewed from each of the 30 fields of oil immersion objective of a microscope (Coles, 1989). The blood samples were centrifuged and serum was separated to estimate some biochemical parameters, i.e. serum cholesterol (Allain, et al., 1974), triglycerides (TG) (Fossati and Prencipl., 1982), high density lipoprotein-cholesterol (HDL-c) (Lopes-Virella et al., 1977), low density lipoprotein-cholesterol (LDL-c) (Friedewald, et al., 1972), aspartate aminotransferase (AST) and Alanine aminotransferase (ALT) (Reitman and Frankl 1957). Alkaline Phosphatase (AlP) (Principato et al., 1985).

Malondialdehyde (MDA), superoxide dismutase (SOD) and glutathione peroxidase (GPx) level were measured by the method of Mihara and Uchiyama 
(1978). Gamma glutamyl transpeptidase (GGT) and Catalase (CAT) were determined by the method of Fiala et al., (1972) and Sinha (1972) respectively. Serum urea and creatinine levels were also determined using photoelectric colorimeter as described by (Coles, 1989). Total protein (TP) and Albumin concentrations were determined by the methods of Henry et al., (1974) and Doumas et al. (1977), respectively.

\section{Histopathology}

All the animals from each of the experimental groups 1, 2, 3, 4 and the control were sacrificed $24 \mathrm{~h}$ after their respective daily doses. The rats were thereafter quickly dissected to remove the liver and then transferred into $10 \%$ buffered formalin. The organs were dehydrated in ethanol (70 to $100 \%$ ), cleared in xylene and embedded in paraffin. Tissue sections were examined under a light microscope after staining with haematoxylin and eosin (H and E) (Culling, 1963; Lillie, 1965).

Statistical analysis

Data are presented as means \pm SD and the analysis was conducted using SPSS program, Version 16.0 (SPSS, 2007).

\section{RESULTS AND DISCUSSION}

\section{Effect of Moringa leaves and seeds powder on Erythrogram analysis:}

Table (1) illustrated the effect of Moringa leaves and seeds powdered on erythrogram analysis. Erythrogram analysis were observed in rats that received the high dose treatment with Moringa oleifera and silymarin.

Data in the same table cleared that, insignificant different in hemoglobin, red blood cell, packed cell volume, mean cell volume, mean corpuscular hemoglobin and mean corpuscular hemoglobin concentration between a groups.

\section{Effect of Moringa leaves and seeds powder on total and deferential Leukocyte count:}

Table (2) illustrated the effect of Moringa leaves and seeds powdered on total and deferential Leukocyte count. Result revealed that, treating with Moringa and silymarin lead to increase in lymphocytes. As well as insignificant different in while blood cell, eosinophil and monocytes between all groups.

Table 1. Effect of Moringa leaves and seeds powder on Erythrogram analysis

\begin{tabular}{cccccccc}
\hline Group & $\begin{array}{c}\mathbf{H b} \\
\mathbf{\%}\end{array}$ & $\begin{array}{c}\mathbf{R B C} \\
\times \mathbf{1 0}\end{array}$ & $\begin{array}{c}\mathbf{P C V} \\
\mathbf{\%}\end{array}$ & $\begin{array}{c}\mathbf{M C V} \\
\mathbf{f L}\end{array}$ & $\begin{array}{c}\mathbf{M C H} \\
\mathbf{p g}\end{array}$ & $\begin{array}{c}\text { MCHC } \\
\mathbf{g} / \mathbf{d l}\end{array}$ & $\begin{array}{c}\text { Platelet } \\
\times \mathbf{1 0} / \boldsymbol{l} \boldsymbol{l}\end{array}$ \\
\hline Control (-) & $13.17 \pm$ & $4.40 \pm$ & $40.50 \pm$ & $89.93 \pm$ & $29.77 \pm$ & $32.43 \pm$ & $386.33 \pm$ \\
& $1.19^{\mathrm{a}}$ & $0.26^{\mathrm{a}}$ & $3.57^{\mathrm{a}}$ & $3.67^{\mathrm{a}}$ & $2.27^{\mathrm{a}}$ & $0.057^{\mathrm{a}}$ & $28.29^{\mathrm{b}}$ \\
Control (+) & $14.43 \pm$ & $4.90 \pm$ & $44.30 \pm$ & $89.73 \pm$ & $29.43 \pm$ & $32.53 \pm$ & $194.67 \pm$ \\
& $0.47^{\mathrm{a}}$ & $0.17^{\mathrm{a}}$ & $1.42^{\mathrm{a}}$ & $3.23^{\mathrm{a}}$ & $0.84^{\mathrm{a}}$ & $0.05^{\mathrm{a}}$ & $6.5^{\mathrm{a}}$ \\
MOLP10\% & $14.03 \pm$ & $4.87 \pm$ & $43.10 \pm$ & $88.60 \pm$ & $28.87 \pm$ & $32.50 \pm$ & $206.67 \pm$ \\
& $0.58^{\mathrm{a}}$ & $0.31^{\mathrm{a}}$ & $1.75^{\mathrm{a}}$ & $3.03^{\mathrm{a}}$ & $0.98^{\mathrm{a}}$ & $0.0^{\mathrm{a}}$ & $23.69^{\mathrm{a}}$ \\
MOSP 5\% & $13.10 \pm$ & $4.60 \pm$ & $40.30 \pm$ & $87.60 \pm$ & $28.43 \pm$ & $32.46 \pm$ & $231.67 \pm$ \\
& $0.56^{\mathrm{a}}$ & $0.1^{\mathrm{a}}$ & $1.67^{\mathrm{a}}$ & $3.42^{\mathrm{a}}$ & $1.11^{\mathrm{a}}$ & $0.05^{\mathrm{a}}$ & $27.54^{\mathrm{a}}$ \\
Silymarin & $13.80 \pm$ & $4.70 \pm$ & $42.13 \pm$ & $90.20 \pm$ & $29.33 \pm$ & $32.46 \pm$ & $270.16 \pm$ \\
& $1.73^{\mathrm{a}}$ & $0.56^{\mathrm{a}}$ & $2.42^{\mathrm{a}}$ & $3.48^{\mathrm{a}}$ & $1.17^{\mathrm{a}}$ & $0.11^{\mathrm{a}}$ & $37.61^{\mathrm{a}}$ \\
\hline
\end{tabular}

Values are expressed as mean \pm SD

${ }^{\mathrm{b}}$ Mean with the same letter in each column are not significant different $(\mathrm{P}<0.05)$

Table 2. Effect of Moringa leaves and seeds powder on total and deferential Leukocyte count

\begin{tabular}{lcccccc}
\hline \multicolumn{1}{c}{ Group } & $\begin{array}{c}\text { TLC } \\
\times \mathbf{1 0}\end{array}$ & $\begin{array}{c}\text { Baso } \\
(\boldsymbol{\%})\end{array}$ & $\begin{array}{c}\text { Eosin. } \\
(\boldsymbol{\%})\end{array}$ & $\begin{array}{c}\text { Neut. } \\
(\boldsymbol{\%})\end{array}$ & $\begin{array}{c}\text { Lymph. } \\
(\boldsymbol{\%})\end{array}$ & $\begin{array}{c}\text { Mono. } \\
(\boldsymbol{\%})\end{array}$ \\
\hline Control (-) & $7.97 \pm 0.45^{\mathrm{a}}$ & 0 & $1.67 \pm 0.57^{\mathrm{a}}$ & $25.67 \pm 4.93^{\mathrm{a}}$ & $68.33 \pm 5.77^{\mathrm{ab}}$ & $4.00 \pm 1.00^{\mathrm{a}}$ \\
Control (+) & $7.92 \pm 0.42^{\mathrm{a}}$ & 0 & $2.33 \pm 0.58^{\mathrm{a}}$ & $31.67 \pm 2.08^{\mathrm{a}}$ & $62.67 \pm 3.21^{\mathrm{a}}$ & $3.33 \pm 0.58^{\mathrm{a}}$ \\
MOLP10\% & $8.50 \pm 0.10^{\mathrm{a}}$ & 0 & $0.67 \pm 0.50^{\mathrm{a}}$ & $22.66 \pm 4.50^{\mathrm{ab}}$ & $73.33 \pm 4.72^{\mathrm{ab}}$ & $3.67 \pm 1.52^{\mathrm{a}}$ \\
MOSP5\% & $8.63 \pm 1.53^{\mathrm{a}}$ & 0 & $2.33 \pm 1.15^{\mathrm{a}}$ & $13.68 \pm 3.21^{\mathrm{ab}}$ & $80.32 \pm 3.10^{\mathrm{b}}$ & $4.00 \pm 1.00^{\mathrm{a}}$ \\
Silymarin & $9.06 \pm 0.29^{\mathrm{a}}$ & 0 & $1.33 \pm 1.52^{\mathrm{a}}$ & $23.62 \pm 2.08^{\mathrm{ab}}$ & $72.33 \pm 2.30^{\mathrm{ab}}$ & $2.67 \pm 0.57^{\mathrm{a}}$ \\
\hline
\end{tabular}

Values are expressed as mean \pm SD

${ }^{\mathrm{ab}}$ Mean with the same letter in each column are not significant different $(\mathrm{P}<0.05)$ 


\section{Effect of Moringa leaves and seeds powder on serum lipids fractions}

Table (3) illustrated the effect of Moringa leaves and seeds powdered on lipid fractions. The values of serum cholesterol triglycerides, LDL-c , HLDL-c mg/dl) showed significant increase $(\mathrm{P}<0.05)$ in compared with control negative group while HDL-c value $(\mathrm{mg} / \mathrm{dl})$ for control positive group was significantly lower than that of control (-) group. Data in this table showed that, total cholesterol (mg/dl) were increased significantly $(\mathrm{P}<0.05)$ for rats (control+). The statistical analysis showed a significant decrease in total cholesterol of all treated groups with MOLP10\% and MOSP5\% powder when compared with (control +). The lowest decrease in all treated group in cholesterol was recorded in MOLP10\% $(90.00 \pm 2.00)$. Also, the best result of serum triglycerides level was observed in the group fed on basal diet silymarin $(350 \pm 4.36)$. The ameliorated effect of Moringa oleifera on lipid peroxidation may be attributed to the antioxidative phytochemicals present in it especially flavonoids. Flavonoids are the most promising agents for treatment of oxidative stressrelated disease (Babu, et al., 2013). HDL-c among all groups fed on hypercholestreolemic diet containing Moringa oleifera $10 \%$ and $5 \%$ showed significant increase compared with (control + ) and the best results found in group fed on MOLP10\% followed by that fed on MOSP5\%. Low density lipoprotein cholesterol (LDL-c) of all treated rats with basal diet containing
MO powdered decreased significantly $(\mathrm{P}<0.05)$ compared with control (+). Meanwhile these treatments for rats led to increase LDL-c significantly, compared to (control -). Flavonoids and saponins in Moringa leaves are reported to increase HDL-c and lower LDL-c in hypercholesterolemic rats (Mehta, et al., 2003). They were inhibiting inhibition of cholesterol micellar solubility (Chávez-Santoscoy, et al., 2013). Thus, both of these bioactive compounds founds in the aqueous extract have been reported to have hypolipidemic effects (Adedapo, et al., 2015; Leone, et al., 2015).

\section{Effect of Moringa oleifera leaves and seeds powder on liver functions:}

Results of AST, ALT, and ALT are presented in table (4), AST in all treated groups recorded significant decrease $(\mathrm{P}<0.05)$ when compared with $($ control +$)$. On the other hand, the lowest levels of AST enzymes were found in group of rats fed on diet containing MOLP10\% (122.67 \pm 11.93$)$. Also, results showed that there were a significant increase $(\mathrm{P}<0.05)$ in the mean values of ALT enzyme in the group fed on (control + ) when compared with all treated groups and the best results were observed in the groups that fed on the MOLP10\% and MOSP5\% respectively.

Mustafa, et al., (2016) reported that, phytochemical screening of Moringa oleifera revealed the presence of alkaloids, carbohydrates, glycosides, flavonoids, tannins, coumarins and triterpenoids.

Table 3. Effect of Moringa leaves and seeds powder on serum lipids fractions

\begin{tabular}{lcccc}
\hline \multicolumn{1}{c}{ Group } & $\begin{array}{c}\text { Cholesterol } \\
\text { mg/dl }\end{array}$ & $\begin{array}{c}\text { TG } \\
\text { mg/dl }\end{array}$ & $\begin{array}{c}\text { HDL-c } \\
\text { mg/dl }\end{array}$ & $\begin{array}{c}\text { LDL-c } \\
\text { mg/dl }\end{array}$ \\
\hline Control (-) & $94.67 \pm 3.51^{\mathrm{b}}$ & $46.00 \pm 3.00^{\mathrm{b}}$ & $40.00 \pm 7.00^{\mathrm{ab}}$ & $45.46 \pm 6.73^{\mathrm{b}}$ \\
Control (+) & $127.67 \pm 2.52^{\mathrm{a}}$ & $86.67 \pm 5.77^{\mathrm{a}}$ & $32.33 \pm 1.52^{\mathrm{b}}$ & $78.00 \pm 4.58^{\mathrm{a}}$ \\
MOLP10\% & $90.00 \pm 2.00^{\mathrm{b}}$ & $42.00 \pm 1.73^{\mathrm{b}}$ & $52.00 \pm 2.00^{\mathrm{a}}$ & $29.60 \pm 3.65^{\mathrm{b}}$ \\
MOSP 5\% & $95.67 \pm 4.93^{\mathrm{b}}$ & $47.33 \pm 7.51^{\mathrm{b}}$ & $45.67 \pm 4.93^{\mathrm{ab}}$ & $40.53 \pm 9.50^{\mathrm{b}}$ \\
Silymarin & $92.67 \pm 10.24^{\mathrm{b}}$ & $35.00 \pm 4.36^{\mathrm{b}}$ & $43.33 \pm 5.86^{\mathrm{ab}}$ & $42.33 \pm 9.02^{\mathrm{b}}$ \\
\hline
\end{tabular}

Values are expressed as mean \pm SD

${ }^{\mathrm{ab}}$ Mean with the same letter in each column are not significant different $(\mathrm{P}<0.05)$

Table 4. Effect of Moringa leaves and seeds powder on liver enzymes (IU/L)

\begin{tabular}{lccc}
\multicolumn{1}{c}{ Group } & AST & ALT & ALP \\
\hline Control (-) & $203.00 \pm 13.12^{\mathrm{a}}$ & $50.67 \pm 8.08^{\mathrm{b}}$ & $103.00 \pm 5.67^{\mathrm{ab}}$ \\
Control (+) & $209.33 \pm 12.22^{\mathrm{a}}$ & $61.00 \pm 8.72^{\mathrm{ab}}$ & $91.00 \pm 6.00^{\mathrm{b}}$ \\
MOLP10\% & $122.67 \pm 11.93^{\mathrm{b}}$ & $45.00 \pm 7.00^{\mathrm{b}}$ & $117.67 \pm 2.52^{\mathrm{a}}$ \\
MOSP 5\% & $162.00 \pm 13.43^{\mathrm{ab}}$ & $41.67 \pm 1.53^{\mathrm{b}}$ & $103.33 \pm 7.57^{\mathrm{ab}}$ \\
Silymarin & $188.33 \pm 19.70^{\mathrm{ab}}$ & $77.67 \pm 8.38^{\mathrm{a}}$ & $101.00 \pm 2.00^{\mathrm{b}}$ \\
\hline
\end{tabular}

Values are expressed as mean $\pm \mathrm{SD}$

${ }^{\mathrm{ab}}$ Mean with the same letter in each column are not significant different $(\mathrm{P}<0.05)$ 
Effect of Moringa leaves and seeds powder on oxidative stress biomarkers:

Table (5) showed a malondialdehyde level in serum. Treatment of normal rats with Moringa leaves caused a significant change. In this respect, in hepaotoxic rats Moringa leaves or seeds made a significant reduction in MDA level. Also, in the same table SOD and CAT level serum for group treated with Moringa leaves and seeds led to a significant increase in SOD and CAT compared with the group control positive. Several bioactive compounds including nitrile, mustard oil glycosides and thiocarbamate present in Moringa leaves have been shown to stabilize blood pressure (Minaiyan, et al., 2014). In addition, aqueous extracts of leaves, fruit and seeds of Moringa have antioxidant capacities (Singh, et al., 2009), possibly due to the presence of quercetin and kaempferol in moringa, as they have been reported to have strong antioxidant activity on hepatocyte growth factor-induced oxidation (Labbe, et al., 2009 ; Manal, et al., 2017).

\section{Effect of Moringa oleifera leaves and seeds powder on kidney functions:}

Results in table (6) indicated that, the mean values of urea nitrogen decreased in the groups fed on leaves $10 \%$ and seeds $5 \%$ compared with (Control+). Also, the highest decrease in serum urea nitrogen in all treated groups was found in the group fed on diet containing MOLP10\%. While the highest increase in serum urea nitrogen was observed in silymarin group.
Polyphenolic compounds have all been shown to attenuate the renal dysfunction, improve the renal architecture, increase the antioxidant enzyme activity, decrease lipid peroxidation and reactive oxygen species in nephrotoxicity (Wongmekiat, et al., 2008). Moustapha, et al. (2013) suggested that the phytochemical constituents in MO could contribute to its antioxidant activity and, thus, nephroprotection. Polyphenols compounds comprise the majority of the phytochemicals found in MO (Verma, et al., 2009).

\section{Histopathological examination of liver:}

Liver of rat from control negative showing the normal histological structure of hepatic lobule (Fig.1), Meanwhile, liver of injected rat with CCL4 and fed on basal diet (control + ) liver of rat from control positive showing steatosis of hepatocytes and perivascular inflammatory cells infiltration (Fig.2). Moreover, liver of rat from MOLP10\% showing steatosis of hepatocytes, Liver of rat from MOLP10\% showing fibroplasia around bile duct with appearance of newly formed bile ductuoles (Fig.3). Liver of rat from MOSP5\% showing vacuolation of hepatocytes and congestion of central vein (Fig.4). Liver of rat from silymarin showing sinusoidal leukocytosis and congestion of hepatic sinusoids (Fig.5). The Moringa oleifera have shown a protective effect against antitubercular drug-induced liver damage in rats (Sharifudin, et al., 2013). Further, histological examinations confirmed a decrease in hepatic damages fibrosis and control the rise of serum aminotransferase activities and globulin level (Hamza, 2010) and to

Table 5. Effect of Moringa leaves and seeds powder on oxidative stress biomarkers

\begin{tabular}{lccccc}
\hline \multicolumn{1}{c}{ Group } & $\begin{array}{c}\text { GGT } \\
\mathbf{u} / \mathbf{l}\end{array}$ & MDA (nmol/gm) & $\begin{array}{c}\text { CAT } \\
(\mathbf{m g} / \mathbf{g m})\end{array}$ & $\begin{array}{c}\text { GPX } \\
(\mathbf{m g} / \mathbf{g m})\end{array}$ & $\begin{array}{c}\text { SOD } \\
(\mathbf{m g} / \mathbf{g m})\end{array}$ \\
\hline Control (-) & $67.33 \pm 2.52^{\mathrm{ab}}$ & $2.43 \pm 0.81^{\mathrm{b}}$ & $5.37 \pm 1.29^{\mathrm{a}}$ & $7.63 \pm 0.80^{\mathrm{a}}$ & $12.03 \pm 0.25^{\mathrm{a}}$ \\
Control (+) & $76.33 \pm 4.73^{\mathrm{a}}$ & $5.37 \pm 0.64^{\mathrm{a}}$ & $3.70 \pm 1.65^{\mathrm{a}}$ & $7.50 \pm 0.36^{\mathrm{a}}$ & $8.63 \pm 0.76^{\mathrm{b}}$ \\
MOLP10\% & $56.33 \pm 4.73^{\mathrm{b}}$ & $1.53 \pm 0.21^{\mathrm{b}}$ & $4.87 \pm 0.55^{\mathrm{a}}$ & $7.00 \pm 0.17^{\mathrm{a}}$ & $10.57 \pm 0.59^{\mathrm{ab}}$ \\
MOSP 5\% & $67.33 \pm 2.52^{\mathrm{ab}}$ & $1.50 \pm 0.81^{\mathrm{b}}$ & $4.20 \pm 3.00^{\mathrm{a}}$ & $8.10 \pm 1.56^{\mathrm{a}}$ & $9.40 \pm 1.14^{\mathrm{b}}$ \\
Silymarin & $60.67 \pm 3.79^{\mathrm{b}}$ & $2.57 \pm 0.56^{\mathrm{b}}$ & $4.06 \pm 0.95^{\mathrm{a}}$ & $7.20 \pm 0.35^{\mathrm{a}}$ & $9.47 \pm 0.89^{\mathrm{b}}$ \\
\hline
\end{tabular}

Values are expressed as mean \pm SD

${ }^{\mathrm{ab}}$ Mean with the same letter in each column are not significant different $(\mathrm{P}<0.05)$

Table 6. Effect of Moringa leaves and seeds powder on kidney functions

\begin{tabular}{lcccc}
\hline \multicolumn{1}{c}{ Group } & $\begin{array}{c}\text { Urea } \\
(\mathbf{m g} / \mathbf{d l})\end{array}$ & $\begin{array}{c}\text { Creatinine } \\
(\mathbf{m g} / \mathbf{d l})\end{array}$ & $\begin{array}{c}\text { T. Protein } \\
(\mathbf{g} / \mathbf{d l})\end{array}$ & $\begin{array}{c}\text { Albumin } \\
(\mathbf{g} / \mathbf{d l})\end{array}$ \\
\hline Control (-) & $28.00 \pm 5.19^{\mathrm{b}}$ & $0.63 \pm 0.15^{\mathrm{a}}$ & $3.50 \pm 1.17^{\mathrm{a}}$ & $2.03 \pm 0.15^{\mathrm{ab}}$ \\
Control (+) & $42.67 \pm 2.52^{\mathrm{a}}$ & $1.15 \pm 0.17^{\mathrm{a}}$ & $6.20 \pm 1.49^{\mathrm{a}}$ & $1.83 \pm 0.12^{\mathrm{b}}$ \\
MOLP10\% & $23.67 \pm 7.37^{\mathrm{b}}$ & $0.733 \pm 0.15^{\mathrm{a}}$ & $6.00 \pm 0.82^{\mathrm{a}}$ & $2.07 \pm 0.57^{\mathrm{ab}}$ \\
MOSP 5\% & $25.66 \pm 3.21^{\mathrm{b}}$ & $0.65 \pm 0.10^{\mathrm{a}}$ & $5.27 \pm 0.65^{\mathrm{a}}$ & $2.10 \pm 0.10^{\mathrm{ab}}$ \\
Silymarin & $27.00 \pm 2.64^{\mathrm{b}}$ & $1.10 \pm 0.39^{\mathrm{a}}$ & $5.89 \pm 1.37^{\mathrm{a}}$ & $2.30 \pm 0.20^{\mathrm{a}}$ \\
\hline
\end{tabular}

Values are expressed as mean \pm SD

${ }^{\mathrm{a} b}$ Mean with the same letter in each column are not significant different $(\mathrm{P}<0.05)$ 


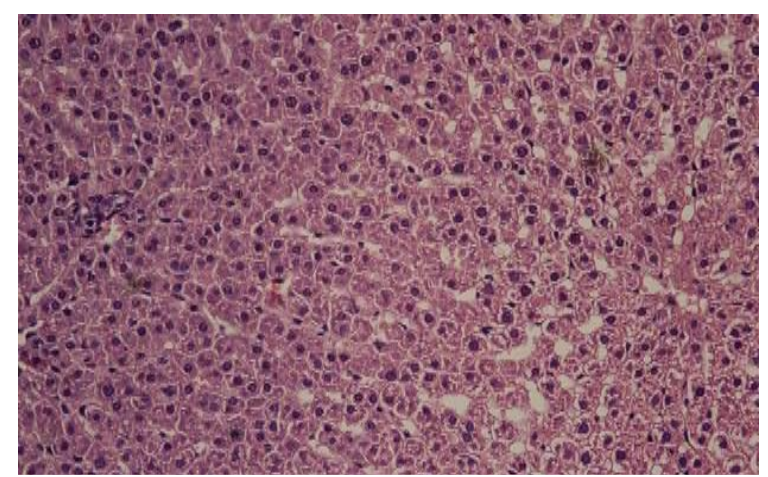

Fig. 1. Liver of rat from control negative showing the normal histological structure of hepatic lobule (H \& E X 400)

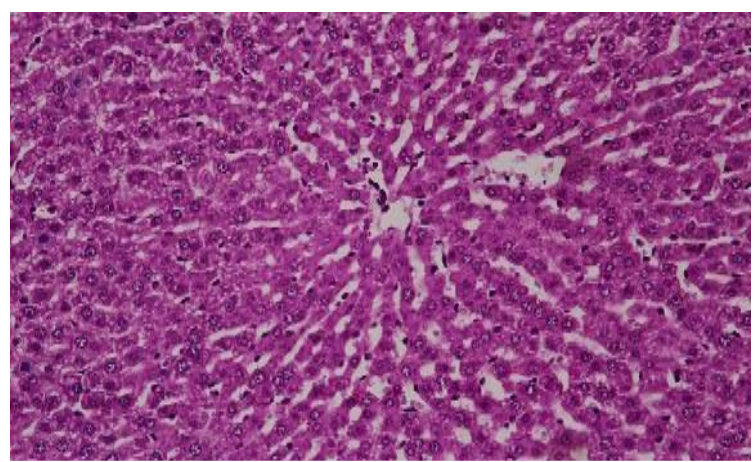

Fig. 3. Liver of rat from MOLP10\% showing steatosis of hepatocytes (H \& E X 400)

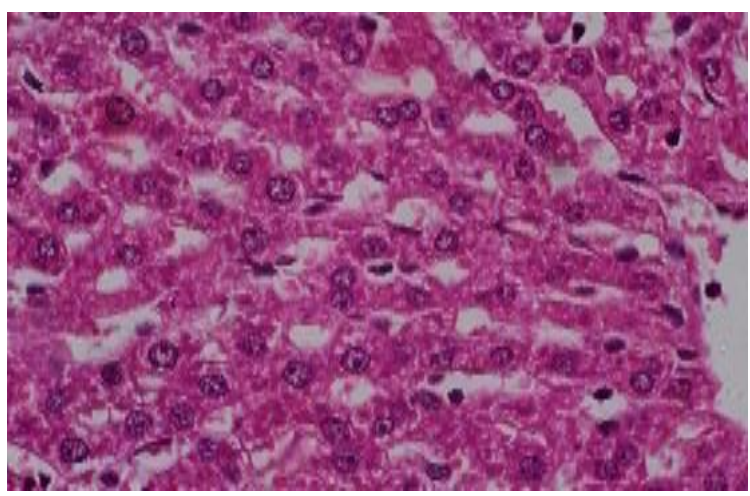

Fig. 2. Liver of rat from control positive showing steatosis of hepatocytes andperivascular inflammatory cells infiltration( $(H \& E X$ X00)

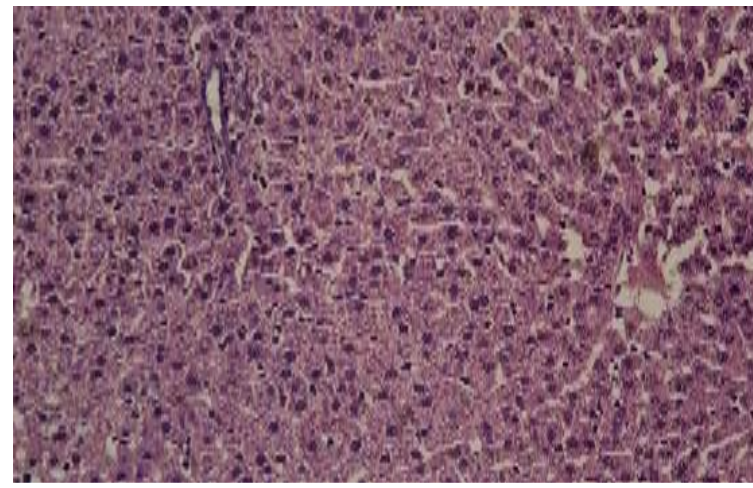

Fig. 4. Liver of rat from MOSP5\% showing vacuolation of hepatocytes and congestion of central vein (H \& E X 400)

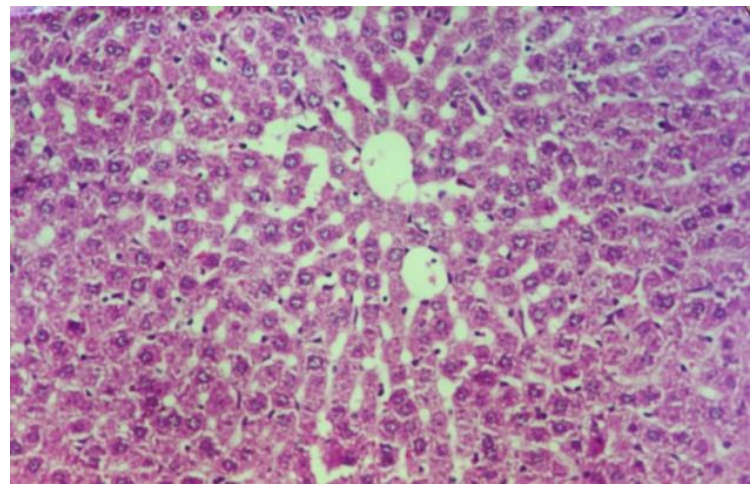

Fig. 5. Liver of rat from silymarin showing no histopathological changes (H \& E X 400) 
protect liver exposed to ionizing radiation by increasing antioxidant enzymes and inhibiting nuclear factor $\mathrm{\kappa B}$ (NF- $\kappa B$ ) translocation to the nucleus (Sinha, 2011).

From the obtained results it can be concluded that, supplementation with high percentage of Moringa oleifera powdered (10\%) exerts a positive impact on the lipid profile and other biochemical parameters in hepatic rats. As well as Moringa oleifera is recommended to be ingested as fresh plant to hepatic patients.

\section{REFERENCES}

Adedapo, A.A., O.O. Falayi and A.A. Oyagbemi. 2015. Evaluation of the analgesic, anti-inflammatory, antioxidant, phytochemical and toxicological properties of the methanolic leaf extract of commercially processed Moringa oleifera in some laboratory animals. J. Basic Clin. Physiol. Pharmacol. 26: 491-499.

Ajayi, T. O., J. O. Moody and C. O. Akintayo. 2016. Toxicological evaluation of Moringa oleifera Lam seeds and leaves in Wistar rats. Pharmacogn. Commn. 6(2) :100-111.

Alcaraz-Contreras, Y., R.P. Mendoza-Lozano, E.R. Martínez-Alcaraz, M. Martínez-Alfaro, M.A. GallegosCorona, M.A. Ramírez-Morales and M.A. VázquezGuevara. 2016. Silymarin and dimercaptosuccinic acid ameliorate lead-induced nephrotoxicity and genotoxicity in rats. Hum Exp Toxicol. 35:398-403.

Allain, C. Z., L. S. Poon and C. S. Chan. 1974.Enzymatic determination of total serum cholesterol. Clin. Chem. 20:470-475.

Amaglo, N.K. , R.N. Bennett, R.B. LoCurto, E.A. Rosa, V. LoTurco and A.Giuffrid. 2010. Profiling selected phytochemicals and nutrients in different tissues of the multipurpose tree Moringa oleifera L., grown in Ghana. Food Chem. 122:1047-54.

Anwar, F.S., M. A. Latif and A.H. Gilani. 2007. Moringa oleifera: A food plant with multiple medicinal uses. Phytother Res. 21: 17- 25.

Aslam, M., F. Anwar, R. Nadeem, U. Rashid, T. Kazi and M. Nadeem. 2005. Mineral composition of Moringa oleifera leaves and pods from different regions of Punjab, Pakistan. Asian J Plant Sci. 4:417-21.

Campbell, J. A. 1963. Methodology of protein evaluation. RAG. Nutrition DOC.R. 10/Led 37.June Meeting, New York.

Chávez-Santoscoy, R.A., J.A. Gutiérrez-Uribe and S.O. Serna-Saldívar. 2013. Effect of flavonoids and saponins extracted from black bean (Phaseolus vulgaris L.) seed coats as cholesterol micelle disruptors. Plant Foods Hum. Nutr. 68: 416-423.

Coles, E.H. 1989. Veterinary Clinical Pathology. 4th Ed. W.B. Saunders Co. USA, pp: 130-148.

Culling, C.F. 1963. Handbook of Histopathological Techniques Iincluding Museum Techniques $2^{\text {nd }}$ Ed., Butterworth and Co., London.
Doumas, B.T., W.A. Watson and H.G. Biggs. 1977.Albumin standards and the measurement of serum albumin with bromocresol green. Clin. Chem. Acta 31: 87-96.

Duncan, J.R., K.W. Prasse and E.A. Mahaffey. 1994. Veterinary Laboratory Medicine (Clinical Physiology), $3^{\text {rd }}$ Edn., Iowa State University Press.

Farooq, F., M. Rai, A. Tiwari, A. Khan and S. Farooq. 2012.Medicinal properties of Moringa oleifera : an overview of promising healer. J Med Plant Res. 6:43684374 .

Fiala, S., A.E. Fiala and B. Dixon. 1972. Gamma glutamyl transpeptidase in chemically induced rat hepatomas and spontaneous mouse hepatomas. J. Natl Cancer Inst. 48: 1393- 1409.

Fossati, P. and L. Prencipl. 1982.Enzymatic colorimetric determination of serum triglycerides. Clin. Chem. 28:2077.

Friedewald, W. T., R. I. Leve and D. S. Fredrichson. 1972. Estimation of concentration of low-density lipoproteins separated by three different. Clin. Chem. 18:499-502.

Gowrishankar, R., M. Kumar, V. Menon, S.M. Divi, M. Saravanan and P. Magu-dapathy. 2010. Trace element studies on Tinospora cordifolia (Menispermaceae), Ocimum sanctum (Lamiaceae), Moringa oleifera (Moringaceae) and Phyllanthus niruri (Euphorbiaceae) using PIXE. Biol Trace Elem Res.133:357-63.

Hamza, A.A. 2010. Ameliorative effects of Moringa oleifera Lam seed extract on liver fibrosis in rats. Food Chem. Toxicol. 48:345-355.

Hegested, D. M., R. C. Mills, C. A. Elvehjem and E. B. Hart. 1941. Choline in the nutrition of chicks. J. Biol. Chem. 138: 459-470.

Henry, R.J., D.C. Cannon and J.W. Winkelman. 1974. Clinical Chemistry Principles and Techniques, eleventh ed. Harper and Row, New York, p. 1629.

Jahn, S.A. 1988.Using Moringa oleifera seeds as coagulant in developing countries. J. Am. Water Works Assoc. 6: 4350.

Jayasekhar, P., P.V. Mohanan and K. Rathinam. 1997. Hepatoprotective activity of ethyl acetate extract of Acacia catechu. Indian Journal of Pharmacol. 29: 426428.

Johnson, B.C. 2005 Clinical perspectives on the health effects of Moringa oleifera : a promising adjunct for balanced nutrition and better health, vol. 8. KOS Health Publication. P: 1-5.

Kasolo, J.N, G.S. Bimenya, L. Ojok, J. Ochleng and J.W. Ogwal-Okeng. 2010. Phyto- chemicals and uses of Moringa oleifera leaves in Ugandan rural communities. J Med Plant Res. 4:753-7.

Kou, X., B. Li, J. Olayanju, J. Drake and N. Chen. 2018. Nutraceutical or Pharmacological Potential of Moringa oleifera Lam. Nutrients. 10(3):343- 350. 
Labbe, D., M. Provencal, S. Lamy, D. Boivin, D. Gingras, R. Beliveau, R. Be and M. Provenc. 2009. The flavonols quercetin, kaempferol, and myricetin inhibit hepatocyte growth factor-induced medulloblastoma cell migration. J. Nutr. 139: 646-652.

Lako, J., V.C. Trenerry, M. Wahlqvist, N. Wattanapenpaiboon, S. Sotheeswaran and R. Premier. 2007. Phytochemical flavonols, carotenoids and the antioxidant properties of a wide selection of Fijian fruit, vegetables and other readily available foods. Food Chem J.101:1727-41.

Leone, A., A. Spada, A. Battezzati, A. Schiraldi, J. Aristil, and S. Bertoli. 2015.Cultivation, genetic, ethnopharmacology, phytochemistry and pharmacology of Moringa oleifera leaves: An overview. Int. J. Mol. Sci. 16: 12791-12835.

Lillie, R.D. 1965. Histopathologic Technic and Practical Histochem $3^{\text {rd }}$ Edn. Blakiston Division, McGraw-Hill Book Co. New York.

Lopes-virella, M. F., S.Stone, S. Ellis and J. Collwell. 1977. Cholesterol determination in high density lipoproteins separated by three different methods. Clin. Chem.; 23 (5) 882.

Manal, M. A., V. J. Marcela, H. N. Gregory, N. B. Christopher and L. F. Maria. 2017. Article, Moringa Leaves Prevent Hepatic Lipid Accumulation and Inflammation in Guinea Pigs by Reducing the Expression of Genes Involved in Lipid Metabolism. Int. J. Mol. Sci. 18: 1330

Manguro, L.O. and P. Lemmen. 2007. Phenolics of Moringa oleifera leaves. Nat Prod Res .21:56-68.

Mbikay, M. 2012. Therapeutic potential of Moringa oleifera leaves in chronic hyperglycemia and dyslipidemia: a review. Front Ethnopharmacol. 3:1-12.

Mehta, L.K., R. Balaraman, A.H.Amin, P.A. Bafna and O.D. Gulati. 2003. Effect of fruits of Moringa oleifera on the lipid profile of normal and hypercholesterolaemic rabbits. J. Ethnopharmacol. 86: 191-195.

Mihara, M. and M. Uchiyama.1978. Determination of malonaldehyde precursor in tissues by thiobarbituric acid test. Anal. Biochem. 86 (1):271- 278.

Minaiyan, M., G. Asghari, D. Taheri, M .Saeidi and S. NasrEsfahani. 2014. Anti-inflammatory effect of Moringa oleifera Lam seeds on acetic acid-induced acute colitiis in rats. Avicenna J. Phytomed. 4:127-136.

Moustapha, O., L. Assita, R.Norbert, S. O.Aimé, O. Moussa, P. Z.Salifou, G. Olga, D. Pierre and I. G. Pierre. 2013. Protective effect of Moringa oleifera leaves against gentamicin-induced nephrotoxicity in rabbits. Experimental and Toxicologic Pathology. 65:335-339.
Mustafa, A. H. , A. K. Gaber, M. E. Salah and A. A. Ibrahim. 2016. Effects of Moringa oleifera Lam (Moringaceae) Seeds in Rats Fed with High Fat Diet. J.of Pharmaceutical, Chemical and Biological Sci. 4 (1): 7687.

Principato, G.B., M.C.Asia, V. Talesa, G. Rosi and E. Giovannini. 1985.Characterization of the soluble alkaline phosphatase from hepatopancreas of Squilla mantis L. Comp. Biochem. Physiol. 80B:801-804.

Reeves, P. G., F. H. Nielsen and G. C. Fahmy. 1993. Reported of the American Institute of Nutrition adhoc wriling committee on the reformulation of the AIN-76 A Rodent diet. J. Nutr. 123: 1939-1951.

Reitman, S. and S. Frankel. 1957.Acolorimetric methods for the determination of serum glutamic oxaloacetic and glutamic pyruvic transaminase. Am.J. Clin. Path. 28 (1): $56-63$

Sharifudin, S.A., S. Fakurazi, M.T. Hidayat, I. Hairuszah, M. Aris Mohd Moklas and P. Arulselvan. 2013. Therapeutic potential of Moringa oleifera extracts against acetaminophen-induced hepatotoxicity in rats. Pharm. Biol. 51: 279-288.

Singh, B.N., B.R. Singh, R.L. Singh, D. Prakash, R. Dhakarey, G. Upadhyay and H.B. Singh. 2009. Oxidative DNA damage protective activity, antioxidant and anti-quorum sensing potentials of Moringa oleifera. Food Chem. Toxicol. 47:1109-1116.

Sinha ,K.A. 1972.Colorimetric assay of catalase. Anal. Biochem. 47: 389- 394

Sinha, M., D.K. Das, S. Bhattacharjee, S. Majumdar and S. Dey. 2011. Leaf extract of Moringa oleifera prevents ionizing radiation-induced oxidative stress in mice. J. Med. Food. 14: 1167-1172.

SPSS. 2007.Statistical Package for Social Science, SPSS Inc., Chicago, IL, USA Copyright $(\subset$ for Windows, version 16.0 .

Verma, A.R. M. Vijayakumar, C.S. Mathela and C.V. Rao. 2009. In vitro and in vivo antioxidant properties of different fractions of Moringa oleifera leaves. Food Chem Toxicol. 47:2196201.

Von Maydell, H.J. 1986.Trees and shrubs of Sahel, their charac- terization and uses. Eschborn, Germany. P:334-7.

Wongmekiat, O., N. Leelarugrayub and K. Thamprasert. 2008. Beneficial effect of shallot (Allium ascalonicum L.) extract on cyclosporine nephrotoxicity in rats. Food Chem Toxicol. 46:1844-50. 


\section{الملخص العربي}

التأثير الوقائى لأولق وبذور المورينجا على التسمم الكبدى المحدث بواسطة رابع كلوريد الكربون في الفئران

سوزان عبد الرحمن أبوشال

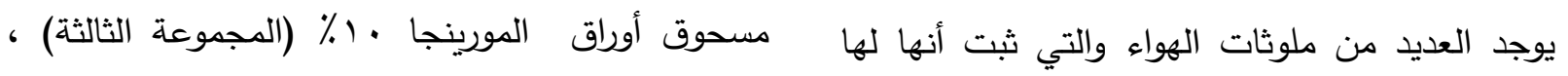

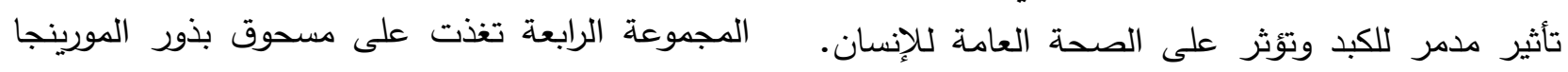

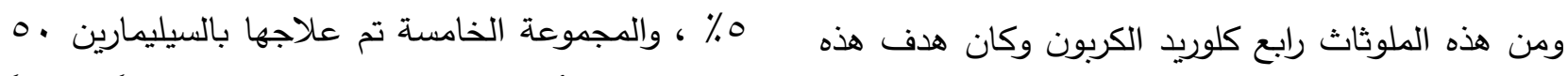

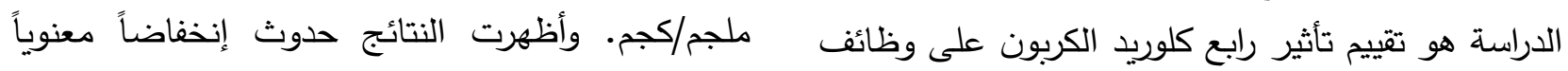
لدستوى الكولستيرول الكلى والدهون الثثلاثية والبروتيات الدهنية منخفضة الكثافة وكذلك إنزيمات الكبد ومستوى

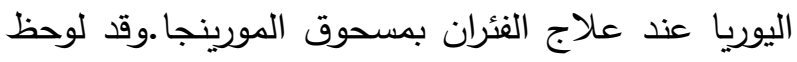

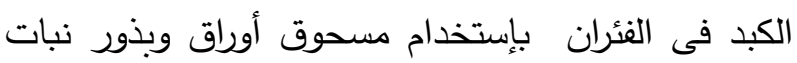
المورينجا. وقد تم إستخدام •ـ من ذكور الفئران وتم تقسيمها إلى خمس مجموعات متساوية ثم إلى ثناء المجموعة الأولى غذاء قياسي (مجموعة ضابطة سالبة)

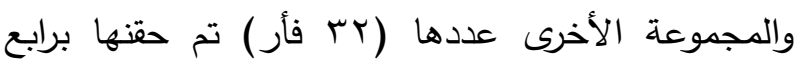

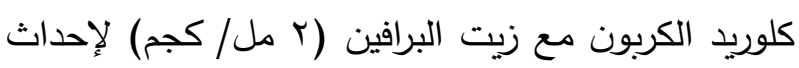

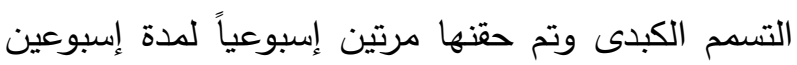

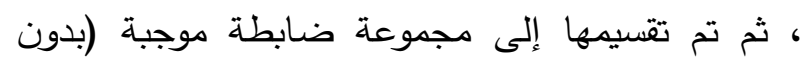

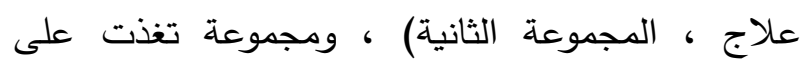

